International Research Journal of Management, IT \& Social Sciences
Available online at https://sloap.org/journals/index.php/irjmis/
Vol. 7 No. 3, May 2020, pages: 29-37
ISSN: 2395-7492
https://doi.org/10.21744/irjmis.v7n3.883

\title{
Influence of the Quality of Human Resources, Communication Information Technology, and Product Mounting Requirements on Product Performance
}

\author{
Putu Eka Juliana Jaya ${ }^{\text {a }}$ \\ Made Suyana Utama ${ }^{b}$ \\ I G.W. Murjana Yasa ${ }^{c}$ \\ Ni Nyoman Yuliarmi ${ }^{\mathrm{d}}$
}

Article history:

Submitted: 18 January 2020

Revised: 27 February 2020

Accepted: 09 March 2020

\section{Keywords:}

HR quality;

ICT;

mounting product requirement;

product performance;

small and medium enterprises;

\begin{abstract}
Improving community welfare is one of the main objectives of a development process in all countries, including Indonesia. Small and Medium Industries (IKM) have contributed significantly to the development of the Indonesian economy through the export, trade, and supporting employment growth sectors. The purpose of this study is to determine the effect of the quality of human resources, information and communication technology and mounting product requirements on product performance (a study of SMEs in the City of Denpasar). This research method uses a quantitative approach that is analyzed using structural equation analysis (SEM) PLS with a sample of 126 business operators in the city of Denpasar. The results of this study are the quality of human resources, information and communication technology and mounting product requirements have a positive and significant effect on product performance. Product performance of 55.5 percent is influenced by variables in the study. Suggestions for further research are that researchers can then add other variables related to product quality outside of this study such as money, markets, and more specific materials, this is because there is still 44.5 percent of other factors outside this research that affect product performance.
\end{abstract}

International research journal of management, IT and social sciences (C) 2020. This is an open access article under the CC BY-NC-ND license (https://creativecommons.org/licenses/by-nc-nd/4.0/).

Corresponding author:

Putu Eka Juliana Jaya,

Faculty of Economics and Business

Udayana University, Denpasar, Indonesia.

Email address: wawaarjaya@yahoo.com

\footnotetext{
Udayana University, Denpasar, Indonesia

b Udayana University, Denpasar, Indonesia

Udayana University, Denpasar, Indonesia

${ }^{\mathrm{d}}$ Udayana University, Denpasar, Indonesia
} 


\section{Introduction}

Small and Medium Industries (IKM) have contributed significantly to the development of the Indonesian economy through the export, trade, and supporting employment growth sectors. IKM can also flexibly adapt to the tides and the direction of market demand. In connection with the outbreak of the ASEAN Economic Community (AEC) in 2015, the efforts of SMEs must also adapt to current developments. Through the AEC, there will be free trade and the loss of trade tariffs between ASEAN countries and the flow of labor between ASEAN countries. IKM must be able to improve the quality of products produced to deal with foreign products that will enter the Indonesian market. On the other hand, MEA also opens access for SMEs to more easily market local products to countries in Southeast Asia. With the MEA agreement being held, ASEAN member countries will compete to become producers to strengthen the country's economy. The cooperative and IKM sectors that are important to be developed in facing MEA are creative and innovative industries, handicrafts, home industries, and information technology.

The shift from the agricultural era to the era of industrialization, then followed by the information age, which was accompanied by many discoveries in the field of communication information technology, has led human civilization into a new arena of social relations that had never been imagined (Toffler \& Alvin, 1980). The world is now flat due to globalization and the development of technology, information, and communication (Friedman 2006; Tapscott, 2008). Moreover, the world of global trade is entering a new phase which causes no more barriers between countries in carrying out international trade. In the 1990s a new economic era began which emphasized the importance of information and creativity, known as the Creative Economy era. This creative economic activity is a series of activities in the production and distribution of goods and services that develop through mastery in the fields of information, knowledge, and creativity. The creative economy becomes a new model of economic management that relies on its activities in the process of value creation and transactions. This economic era not only emphasizes the process of creation and transactions, but also utilizes the synergy of mindset to produce an output that has good quality, high selling value, and unique aesthetic value. The creative economy is then driven by the industrial sector called the Creative Industry.

The Government of Indonesia continues to encourage efforts to develop creative industries (Introduction and Direction of Development of Indonesia's Creative Economy 2025, Ministry of Trade of the Republic of Indonesia). The government views this industry as being able to improve the people's economy and the performance of products produced and to develop future industries. With the contribution of this creative industry, the Government, specifically the Ministry of Cooperatives and Small and Medium Enterprises (SMEs), facilitates efforts to increase the contribution of creative industries to the national economy as a whole through empowering and strengthening Small and Medium Industries (SMEs). Bali is one of the provinces in Indonesia which has a relatively small growth in the SME sector. IKM production in Bali in the third quarter of 2017 only rose 1.10 percent compared to the previous year whereas to achieve the ideal growth rate it should be above 7 percent (Kadin Bali, 2017). Efforts to improve the performance of SMIs in Bali, especially in the city of Denpasar, still face obstacles in providing market opportunities (Kaminski et al., 2008; Gunasekaran et al., 1999; Man et al., 2002; Fink, 1998; Morgan et al., 2003). In addition to capital, which is still the main obstacle, there are other things, such as the use of technology and promotion constraints in marketing their products.

Denpasar City is the Capital of the Province of Bali. The vision of the city of Denpasar is "Creative Denpasar with Cultural Insights in Balance towards Harmony". While its mission is to strengthen the identity of the people of Denpasar based on Balinese culture, empowering the people of Denpasar City based on local wisdom through creative culture, realizing good governance through law enforcement for law, improving public services towards public welfare (Wallfare Society), accelerate growth and strengthen the economic resilience of the community through a system of Economic Democracy (Economic Stability). Regarding Denpasar City as a trade center and industrial center, preobservations have been made to the Denpasar City Cooperative and UMKM Office and the Province of Bali, Denpasar City Industry and Trade Office and to know the general picture and realization of exports in Denpasar City. The realization of exports from SMEs is one measure to assess the potential of an area (Lopez-Acevedo \& Robertson, 2016). Following Denpasar City Industry and Trade Office's report on the realization of Denpasar City's exports from 2014 to 2018, it was stated that there were an increase and development of Denpasar City's exports to all export destination countries. 5 types of important commodities contribute to exports in Denpasar, namely handicraft products, industrial products, agricultural products, plantation products, and other commodity products. It was also stated that handicrafts always contribute to the highest export income, as can be seen in the following Table 1. 
Table 1

Denpasar City IKM Export Value per Commodity in 2014-2018, in thousands of USD

\begin{tabular}{llllllll}
\hline \multirow{2}{*}{ No } & \multirow{2}{*}{ Commodity } & $\begin{array}{l}2014 \\
\text { Value }\end{array}$ & $\begin{array}{l}2015 \\
\text { Value }\end{array}$ & $\begin{array}{l}2016 \\
\text { Value }\end{array}$ & $\begin{array}{l}2017 \\
\text { Value }\end{array}$ & $\begin{array}{l}2018 \\
\text { Value }\end{array}$ & $\begin{array}{l}\text { Total Per } \\
\text { Commodity }\end{array}$ \\
\hline 1 & Handicraft & 173.661 & 154.959 & 156.677 & 177.589 & 166.113 & 1.143 .140 \\
2 & Industrial Products & 112.805 & 110.098 & 108.708 & 92.706 & 107.243 & 745.990 \\
3 & Agricultural product & 108.222 & 111.338 & 71.626 & 152.674 & 219.875 & 874.073 \\
4 & Plantation Products & 881 & 427 & 455 & 667 & 298 & 3.135 \\
5 & Etc & 1.050 & 1.513 & 1.850 & 3.093 & 2.055 & 16.549 \\
& Total & 396.619 & 378.335 & 339.317 & 426.730 & 495.585 & 2.782 .887 \\
\hline
\end{tabular}

Sources: Denpasar City Industry and Trade Office, processed, 2019

There are seventeen handicraft commodities owned by Denpasar City, namely: Musical Instrument Crafts. Weaving Crafts, Bamboo Crafts, Padstone Crafts, Furniture Crafts, Wood Crafts, Ceramic Crafts, Shell Crafts, Leather Crafts, Other Crafts (Spa Products and Cosmetics), Candle Crafts, Metal Crafts, Painting Crafts, Silver Crafts, Rattan Crafts, Terracotta Crafts, and Bone Crafts. The biggest contribution based on the export value from 2012 to 2016 is from wood, furniture, silver, solid stone, and metal crafts as can be seen in Table 2 attached below.

Table 2

2014-2018 Denpasar City IKM handicraft commodity results in thousands of USD

\begin{tabular}{|c|c|c|c|c|c|c|c|}
\hline No & Handicraft & 2014 & 2015 & 2016 & 2017 & 2018 & $\begin{array}{l}\text { Dominant Export } \\
\text { Destination Country }\end{array}$ \\
\hline 1 & $\begin{array}{l}\text { Musical } \\
\text { Instrument Crafts }\end{array}$ & 486 & 425 & 1.108 & 220 & 95 & Australia, China, USA \\
\hline 2 & Woven Crafts & 2.328 & 1.598 & 1.317 & 2.341 & 3.811 & $\begin{array}{l}\text { Japan, Australia, Malaysia, } \\
\text { etc }\end{array}$ \\
\hline 3 & Bamboo Crafts & 11.007 & 5.728 & 6.734 & 3.982 & 3.652 & $\begin{array}{l}\text { Spain, Mexico, USA, } \\
\text { Canada }\end{array}$ \\
\hline 4 & $\begin{array}{l}\text { Padas Stone } \\
\text { Crafts }\end{array}$ & 13.512 & 11.616 & 11.848 & 8.158 & 8.003 & $\begin{array}{l}\text { Thailand, USA, Japan, } \\
\text { Australia }\end{array}$ \\
\hline 5 & Furniture Crafts & 28.541 & 29.641 & 20.597 & 31.430 & 23.118 & $\begin{array}{l}\text { USA, Australia, Maldives, } \\
\text { France, etc }\end{array}$ \\
\hline 6 & Woodcraft & 54.417 & 46.910 & 56.602 & 58.460 & 62.988 & $\begin{array}{l}\text { Maldives, USA, Spain, } \\
\text { England }\end{array}$ \\
\hline 7 & Ceramic Crafts & 1.388 & 1.036 & 1.773 & 765 & 1.393 & $\begin{array}{l}\text { India, USA, Australia, } \\
\text { Germany }\end{array}$ \\
\hline 8 & Seashell Craft & 2.076 & 980 & 1.190 & 1.555 & 1.229 & $\begin{array}{l}\text { Japan, USA, Brazilia, } \\
\text { France }\end{array}$ \\
\hline 9 & LeatherCraft & 8.471 & 9.236 & 9.141 & 4.836 & 4.117 & $\begin{array}{l}\text { Japan, Australia, USA, } \\
\text { Netherland }\end{array}$ \\
\hline 10 & Other Crafts & 10.029 & 4.848 & 7.147 & 13.152 & 15.041 & $\begin{array}{l}\text { USA, Australia, } \\
\text { Netherland, France }\end{array}$ \\
\hline 11 & Candle Craft & 443 & 553 & 271 & 159 & 128 & $\begin{array}{l}\text { USA, Australia, Germany, } \\
\text { etc }\end{array}$ \\
\hline 12 & Metal Crafts & 12.782 & 11.862 & 12.162 & 18.200 & 10.226 & $\begin{array}{l}\text { USA, Japan, Hongkong, } \\
\text { Australia }\end{array}$ \\
\hline 13 & Craft Painting & 2.090 & 1.774 & 1.216 & 1.036 & 1.512 & $\begin{array}{l}\text { Australia, Japan, USA, } \\
\text { Thailand }\end{array}$ \\
\hline 14 & Silver Craft & 19.661 & 25.240 & 26.235 & 28.642 & 23.177 & $\begin{array}{l}\text { USA, Australia, England, } \\
\text { Germany }\end{array}$ \\
\hline
\end{tabular}

Jaya, P. E. J., Utama, M. S., Yasa, I. G. M., \& Yuliarmi, N. N. (2020). Influence of the quality of human resources, communication information technology, and product mounting requirements on product performance. International Research Journal of Management, IT and Social Sciences, 7(3), 29-37. https://doi.org/10.21744/irjmis.v7n3.883 


\begin{tabular}{llllllll}
\hline 15 & Rattan Crafts & 3.959 & 1.674 & 1.681 & 1.729 & 5.045 & $\begin{array}{l}\text { Germany, Dubai, } \\
\text { Australia, Maldives } \\
\text { Australia, USA, Maldives, } \\
\text { etc }\end{array}$ \\
17 & Terracotta Crafts & 2.212 & 1.449 & 1.450 & 2.272 & 1.838 & $\begin{array}{l}\text { USA, France, Netherland, } \\
\text { New Zealand }\end{array}$ \\
\hline
\end{tabular}

Source: Denpasar City Industry and Trade Office, processed, 2019

Several other previous studies on factors that influence the ability of SMEs also become a review material, namely Nicolescu (2009), showing the ability of SMEs / SMEs to be able to survive and grow depending on internal factors that affect company productivity and innovation as well as external factors, Wignaraja (2012), generally shows that SMEs' participation in the Global Value Chain (GVC) is still low due to limited resources such as finance, information, management capacity and technology and access to market information (Wignaraja, 2012). Harvie et al. (2010), stated that what can increase participation in GVC is the scale and maturity of the business, foreign linkage, productivity, innovation and access to finance. The problem that is still faced by SMEs is low productivity (Sri Susilo, 2005). This relates to: (i) the low quality of human resources in micro-scale businesses, and (ii) the low competency of micro-scale business entrepreneurship. IKM also faces factors that are still obstacles in improving the performance of SMIs. These factors are (Susilo \& Maat, 2007): (i) limited access to capital 2, (ii) limited access to markets, and (iii) limited access to information about resources and technology. Creative industries have formed a competitive business competition where everyone can take part in the developing economy. SMEs that are currently developing in Denpasar City still experience several obstacles that constrain their performance processes, such as lack of knowledge access to niche industries and problems in Denpasar City, such as limited access to capital, limited access to wider markets, limited technology and information owned by SMEs in the City of Denpasar. Based on the theoretical study, the results of previous research, as well as the theoretical framework, the hypothesis was developed in this research is "Quality of Human Resources (HR), Information and Communication Technology (ICT), and Mounting Product Requirements (MPR) have a positive effect on Product Performance ( KP) IKM in Denpasar City".

\section{Materials and Methods}

This study uses a quantitative approach (positivism) to determine the associative level of variables with one another while testing the hypotheses that have been prepared. Denpasar City was chosen as the location of the study because it was based on preliminary observations in the field. The time required is six months. The type of data used in this study is qualitative and quantitative data. In this study, the population of all SMIs in the city of Denpasar, the total population per the year 2018 according to data from the Office of Industry and Trade of Bali Province and the Office of Industry and Trade of Denpasar City amounted to 126 units, so that the number of samples was the same as the population. This research uses structural equation analysis (SEM) with alternative Partial Least Square PLS (component-based SEM). The indicators in the research variables used are as follows, namely, in the variable quality of human resources (X1), the indicators used are educated HR, skilled and expert HR, trained HR, and competent HR. In the information and communication technology variable (X2) the indicators used are technology utilization, a technology that increases the value added, and technology that has fast access. In the mounting product requirements variable (X3) indicators used are procedural, quality control, safety, and reliability (Apsari \& Purnomo, 2020). In the product performance variable $(\mathrm{Y})$, the indicators used are performance, conformance to specifications, aesthetics, and perceived quality (Zhou, 2006; Cooper, 1998; Soh, 2003; Djurdjanovic et al., 2003; Bayus, 1997).

\section{Results and Discussions}

Table 3

$\mathrm{R}^{2}$ Research Model

\begin{tabular}{|l|l|l|}
\hline & R Square & R Square Adjusted \\
\hline $\mathrm{Y}$ & 0,555 & 0,541 \\
\hline
\end{tabular}

Source: Processed data, 2019 
Based on an $\mathrm{R}$ square value of 0.555 , it means that 55.5 percent of product quality is explained by the quality of human resources, information technology, and mounting product requirements, while the remaining 44.5 percent is explained by other factors outside the model. Based on the results of bootstrapping, the following results are obtained:

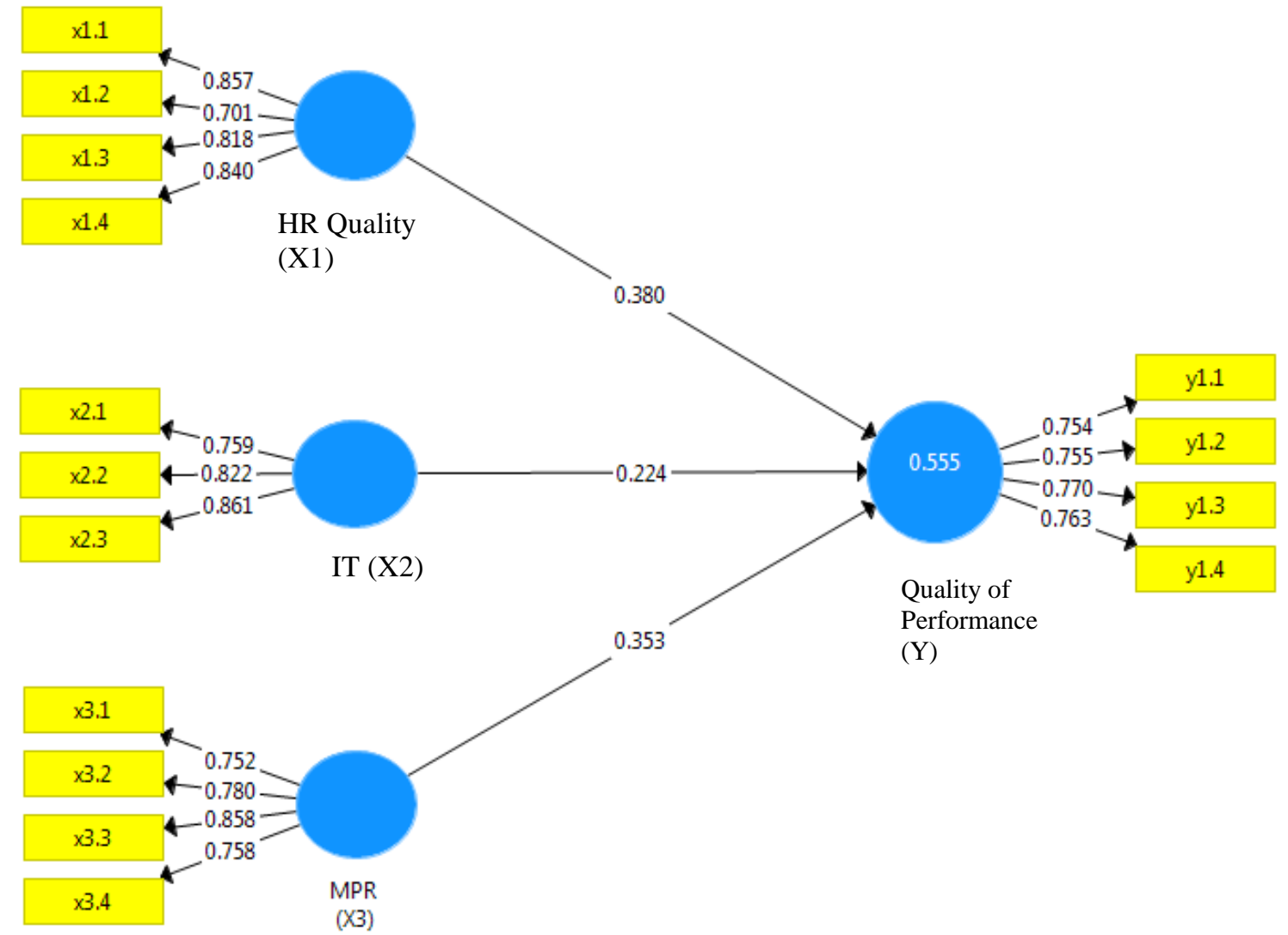

Figure 1. Bootstrapping result

Table 4

Path Coefficients

\begin{tabular}{|l|l|l|l|l|l|}
\hline & $\begin{array}{l}\text { Original } \\
\text { Sample (O) }\end{array}$ & $\begin{array}{l}\text { Sample Mean } \\
(\mathrm{M})\end{array}$ & $\begin{array}{l}\text { Standard Deviation } \\
(\text { STDEV })\end{array}$ & $\begin{array}{l}\text { T Statistics } \\
(|\mathrm{O} / \mathrm{STDEV}|)\end{array}$ & $\begin{array}{l}\text { P } \\
\text { Values }\end{array}$ \\
\hline X1 -> Y & 0,380 & 0,383 & 0,093 & 4,074 & 0,000 \\
\hline X2 -> Y & 0,224 & 0,232 & 0,091 & 2,473 & 0,007 \\
\hline X3 -> Y & 0,353 & 0,356 & 0,087 & 4,039 & 0,000 \\
\hline
\end{tabular}

Source: Data processed, 2019

\section{Discussion}

The influence of the quality of human resources on product performance

The influence of the quality of human resources on product performance amounted to 0.380 with a significance level of $0,000(<\alpha=0.05)$ then the hypothesis was tested positively and significantly. This means that the better the quality of human resources, the product performance will increase by 0.380 . The quality of human resources has a positive and significant impact on product performance, this is because the skilled, trained, competent and educated KSDM plays an important role in improving product performance. This is supported by research from Santoso et al. (2015),

Jaya, P. E. J., Utama, M. S., Yasa, I. G. M., \& Yuliarmi, N. N. (2020). Influence of the quality of human resources, communication information technology, and product mounting requirements on product performance. International Research Journal of Management, IT and Social Sciences, 7(3), 29-37. https://doi.org/10.21744/irjmis.v7n3.883 
which states that human resources have a positive and significant effect on the performance of Agroindustry MSMEs in Malang, Indonesia. Another study by Karendra (2014), stated that the quality of human resources affected the business development of KPRI Pertaguma in Madiun City. This means that if the human resources owned by SMEs in Denpasar have superior quality, they will improve the performance of the products produced. Research Strategies to Improve Umkm's Competitiveness in Dealing with the Implementation of Cafta and Mea by Y. Sri Susilo 2010 using the literature review method to obtain the results of CAFTA implementation has been carried out since January 2010 and the implementation of the MEA will be realized in 2015. With the implementation of CAFTA and MEA in Indonesia MSMEs in Indonesia will face challenges and at the same time obtain opportunities. To be able to survive and be able to take advantage of opportunities, MSMEs must improve the competitiveness of companies and the competitiveness of their products. With a conducive business climate created by the government, it will make it easier for MSMEs to increase competitiveness, both the competitiveness of companies and the competitiveness of products produced. Other stakeholders must improve the partnership that has been established with MSMEs, because the support of stakeholders in the form of education/training/counseling, promotion, and other facilitation has been proven to be able to encourage efforts to significantly enhance MSME competitiveness.

\section{The effect of information and communication technology on product performance}

The effect of information and communication technology on product performance is 0.224 with a significance level of $0.007(<\alpha=0.05)$, the hypothesis is tested positively and significantly. This means that the better the information and communication technology of a business, the product performance will increase by 0.224 . The term Information and Communication Technology (ICT) or Information and Communication Technologies (ICT) became popular in the late 70s. In the past, the term information technology was commonly called computer technology or electronic data processing. ICT is defined as a technology for processing and disseminating data using hardware and software, computers, communications, and digital electronics. ICT is a technology used to process data, including processing, obtaining, compiling, storing, manipulating data in various ways to produce quality information, namely information that is relevant, accurate and timely, which is used for personal, business, and government purposes and is strategic information for decision making. This technology uses a set of computers to process data, a network system to connect one computer to another as needed, and telecommunications technology is used so that data can be disseminated and accessed globally. One example of the massive technology used in the development of SMIs is in the process of marketing products through various online platforms. Thus, ICT, in general, can be interpreted as a broad subject regarding technology and other aspects of how to manage and process data into information. This communication information technology is a subsystem of the information system (information system). Especially in a review from the standpoint of technology. Improving the quality of life increasingly requires humans to carry out various activities that are needed by optimizing their resources. Unknowingly, some of the activities carried out by humans have been supported by Information and Communication Technology. Information and Communication Technology both, directly and indirectly, have a role in changing the way we live, the way we learn, the way we work and the way we play. Some applications of Information and Communication Technology including in the fields of business, education, and health and government. The application of ICT in the business sector, for example, ICT has been widely used to support business processes that occur in companies, both in the economic and banking fields. Based on research by Razleena et al. (2018), it was stated that SMIs are one of the important economic wheels in Malaysia. IKM in Malaysia influences urbanization, employment, distribution of income and welfare per capita and will ultimately affect the quality of life and welfare of the people. One way to improve the performance of local IKM products in the era of globalization is to take advantage of science and technology and the internet, namely by doing IKM business online. This will cut costs and increase the productivity of SMIs, as well as a means to reach networking throughout the world.

\section{The effect of mounting product requirements on product performance}

The effect of mounting product requirements on product performance is 0.353 with a significance level of $0.000(<\alpha$ $=0.05)$ then the hypothesis is tested positively and significantly. This means that the increasing requirements of the production process of a product, the product performance will increase by 0.353 . MPR which can improve product performance with the highest indicator value based on this research is safety. The product development process that prioritizes safety in its manufacture and its use later by consumers will improve product performance. The importance of product safety to meet the demands of product performance is increasingly high, demanding more stringent control of the production process so that the product is carried out more diligently for this it requires careful supervision during 
the production process to meet the expected quality of the product (Feigenbaum, 1994). Increasing global product performance will ultimately also improve the welfare of the country and society through financial outcomes (Dima et al., 2018).

\section{Conclusion}

Based on the discussion, the conclusions that can be given are the quality of human resources, information and communication technology and mounting product requirements have a positive and significant effect on product performance. Product performance of 55.5 percent is influenced by the variables in this study, namely the quality of human resources, information and communication technology, and mounting product requirements. Suggestions that can be given to SMEs in Denpasar, namely the SMEs can pay more attention to the quality of human resources, the technology used and the improvement of the process requirements for product production because this will encourage an increase in the quality of these products which will indirectly increase customer satisfaction. Suggestions for further research are that researchers can then add other variables related to product quality outside of this study such as money, markets, and more specific materials, this is because there is still 44.5 percent of other factors outside this research that affect product performance.

\section{Conflict of interest statement}

The authors declared that they have no competing interests.

\section{Statement of authorship}

The authors have a responsibility for the conception and design of the study. The authors have approved the final article.

\section{Acknowledgments}

We are grateful to two anonymous reviewers for their valuable comments on the earlier version of this paper.

Jaya, P. E. J., Utama, M. S., Yasa, I. G. M., \& Yuliarmi, N. N. (2020). Influence of the quality of human resources, communication information technology, and product mounting requirements on product performance. International Research Journal of Management, IT and Social Sciences, 7(3), 29-37. https://doi.org/10.21744/irjmis.v7n3.883 


\section{References}

Apsari, A. E., \& Purnomo, H. (2020). An Occupational safety and health (OSH) factors identified in Indonesian batik textile small/medium enterprises. International Research Journal of Engineering, IT \& Scientific Research, 6(2), 55-64. https://doi.org/10.21744/irjeis.v6n2.877

Bayus, B. L. (1997). Speed-to-market and new product performance trade-offs. Journal of product innovation management, 14(6), 485-497. https://doi.org/10.1016/S0737-6782(97)00062-3

Cooper, R. (1998). Benchmarking new product performance:: Results of the best practices study. European Management Journal, 16(1), 1-17. https://doi.org/10.1016/S0263-2373(97)00069-8

Dima, A. M., Begu, L., Vasilescu, M. D., \& Maassen, M. A. (2018). The relationship between the knowledge economy and global competitiveness in the European Union. Sustainability, 10(6), 1706. https://doi.org/10.3390/su10061706

Djurdjanovic, D., Lee, J., \& Ni, J. (2003). Watchdog Agent-an infotronics-based prognostics approach for product performance degradation assessment and prediction. Advanced Engineering Informatics, 17(3-4), 109-125. https://doi.org/10.1016/j.aei.2004.07.005

Feigenbaum, A. V. (1991). Total Quality Control: 3d Ed.

Fink, D. (1998). Guidelines for the successful adoption of information technology in small and medium enterprises. International journal of information management, 18(4), 243-253. https://doi.org/10.1016/S02684012(98)00013-9

Friedman, T. L. (2006). The world is flat: The globalized world in the twenty-first century (p. 593). London: Penguin.

Gunasekaran, A., Marri, H. B., \& Grieve, R. J. (1999). Activity based costing in small and medium enterprises. Computers \& Industrial Engineering, 37(1-2), 407-411. https://doi.org/10.1016/S03608352(99)00105-9

Harvie, C., Narjoko, D., \& Oum, S. (2010). Firm characteristic determinants of SME participation in production networks. ERIA discussion paper series, 11, 1-52.

Kaminski, P. C., de Oliveira, A. C., \& Lopes, T. M. (2008). Knowledge transfer in product development processes: a case study in small and medium enterprises (SMEs) of the metal-mechanic sector from Sao Paulo, Brazil. Technovation, 28(1-2), 29-36. https://doi.org/10.1016/j.technovation.2007.07.001

Karendra, I. A. (2016). Pengaruh kualitas sumber daya manusia terhadap perkembangan usaha pada kpri pertaguma kota madiun. Equilibrium: Jurnal Ilmiah Ekonomi dan Pembelajarannya, 4(1), 57-67. http://doi.org/10.25273/equilibrium.v4i1.633

Lopez-Acevedo, G., \& Robertson, R. (Eds.). (2016). Stitches to riches?: Apparel employment, trade, and economic development in South Asia. The World Bank.

Man, T. W., Lau, T., \& Chan, K. F. (2002). The competitiveness of small and medium enterprises: A conceptualization with focus on entrepreneurial competencies. Journal of business venturing, 17(2), 123-142. https://doi.org/10.1016/S0883-9026(00)00058-6

Morgan, F., Massouras, T., Barbosa, M., Roseiro, L., Ravasco, F., Kandarakis, I., ... \& Raynal-Ljutovac, K. (2003). Characteristics of goat milk collected from small and medium enterprises in Greece, Portugal and France. Small Ruminant Research, 47(1), 39-49. https://doi.org/10.1016/S0921-4488(02)00252-3

Nicolescu, O. (2009). Main features of SMEs organisation system. Revista de Management Comparat Internațional, 10(3), 405-413.

Razali, R., Saraih, U. N., Shaari, M. S., Rani, M. J. A., \& Abashah, A. (2018). The influences of effectiveness, competitive advantages and market accessibility on SME Performance in Malaysia. In MATEC Web of Conferences (Vol. 150, p. 05023). EDP Sciences. https://doi.org/10.1051/matecconf/201815005023

Santoso, I., Yuwandini, D., \& Mustaniroh, S. A. (2015). Pengaruh kredit dan sumber daya manusia terhadap kinerja UMKM agroindustri dengan pemasaran sebagai variabel antara. Jurnal Manajemen \& Agribisnis, 12 (3), 174. https://doi.org/10.17358/jma.12.3.174

Soh, P. H. (2003). The role of networking alliances in information acquisition and its implications for new product performance. Journal of business venturing, 18(6), 727-744. https://doi.org/10.1016/S0883-9026(03)00026-0

Sri Susilo, Y. (2005). Strategi Survival Usaha Mikro-Kecil (Studi Empiris Pedagang Warung Angkringan di Kota Yogyakarta). Telaah Bisnis, 6(2), 161-178.

Susilo, Y. O., \& Maat, K. (2007). The influence of built environment to the trends in commuting journeys in the Netherlands. Transportation, 34(5), 589-609. https://doi.org/10.1007/s11116-007-9129-5

Tapscott, D. (2008). Grown up digital. Boston: McGraw-Hill Education.

Toffler, A., \& Alvin, T. (1980). The third wave (Vol. 484). New York: Bantam books. 
Wignaraja, G. (2012). Engaging small and medium enterprises in production networks: Firm-level analysis of five ASEAN economies. https://dx.doi.org/10.2139/ssrn.2071547

Zhou, K. Z. (2006). Innovation, imitation, and new product performance: The case of China. Industrial Marketing Management, 35(3), 394-402. https://doi.org/10.1016/j.indmarman.2005.10.006

Jaya, P. E. J., Utama, M. S., Yasa, I. G. M., \& Yuliarmi, N. N. (2020). Influence of the quality of human resources, communication information technology, and product mounting requirements on product performance. International Research Journal of Management, IT and Social Sciences, 7(3), 29-37. https://doi.org/10.21744/irjmis.v7n3.883 